\title{
UPAYA MENINGKATKAN KETERAMPILAN BERKELOMPOK MAHASISWA DALAM EKOLITERASI KETAHANAN HAYATI MELALUI PEMBELAJARAN KOOPERATIF TIPE INVESTIGASI KELOMPOK, DAN PENDEKATAN ARTISTIK DIGITAL
}

\author{
I Wayan Adiputra Gunawan, I Made Diarta, Sang Putu Kaler Surata \\ Program Studi Pendidikan Biologi, Fakultas Keguruan dan Ilmu Pendidikan, \\ Universitas Mahasaraswati Denpasar
}

\begin{abstract}
ABSTRAK
Permasalahan yang dihadapi dalam penerapan Ekoliterasi Ketahanan Hayati (EKH) pada mahasiswa adalah lemahnya aspek keterampilan sosial dan berkelompok pada mahasiswa. Hal ini bisa diperbaiki dengan pembelajaran kooperatif tipe kelompok investigasi, yang dalam penerapannya menggunakan pendekatan artistik digital (power point). Penerapan EKH ini dilakukan dengan model Penelitian Tindakan Kelas (PTK) melalui dua siklus. Hasilnya penerapan pembelajaran kooperatif kelompok investigasi berbasis pendekatan artistik digital (power point) dapat meningkatkan keterampilan berkelompok mahasiswa dalam presentasi pada aspek fokus dalam presentasi meningkat dari 2,86 menjai 3,73, pada aspek organisasi penyajian dari 2,90 menjadi 3,62, suara dalam presentasi meningkat dari 3,42 menjadi 3,81 serta kemampuan tanya jawab dari 3,18 menjadi 3,85 sedangkan pada aspek pembukaan presentasi terjadi peningkatan dari 2,82 menjadi 3,35 namun peningkatannya tidak signifikan. Penerapan pembelajaran kooperatif kelompok investigasi berbasis pendekatan artistk digital (power point) juga dapat meningkatkan keterampilan mahasiswa dalam menyusun media pembelajaran power point ditinjau penyusunan latar belakang meningkat dari dari 3,17 menjadi 3,56 serta dari keakuratan isi dengan alat bantu meningkat dari 3,12 menjadi 3,62 sedangkan untuk aspek penyusunan gambaran umum meningkat dari 3,38 menjadi 3,76 serta teks yang mencakup pemilihan huruf dan format meningkat dari 3,12 menjadi 3,62 namun peningkatan yang terjadi tidak signifikan.
\end{abstract}

Kata Kunci : Ekoliterasi, ketahanan, hayati, kooperatif, artistik, kelompok, investigasi, digital.

\section{LATAR BELAKANG}

Indonesia merupakan salah satu negara yang memiliki keanekaragaman hayati yang sangat melimpah. Keanekaan hayati yang dimiliki oleh negara Indonesia tentunya memberikan manfaat yang sangat besar bagi kehidupan masyarakat Indonesia. Keanekaan hayati memberikan manfaat yang besar dari sisi peningkatan perekonomian, kesehatan masyarakat, kesejahteraan sosial, dan lain sebagainya. Keanekaan hayati ini merupakan salah satu komponen penting dalam pembangunan nasional di Indonesia. Perkembangan ilmu pengetahuan dan teknologi pada era globalisasi, dapat meningkatkan mobilitas karena adanya peningkatan aktivitas pada sektor perekonomian, kepariwisataan, dan juga perdagangan 
bebas. Kondisi ini dapat menyebabkan terjadinya invasi hayati. Hal ini karena semakin luasnya kesempatan bagi berbagai spesies makhluk hidup untuk saling menyebar dari satu wilayah ke wilayah lainnya, bahkan antar negara. Terjadinya invasi hayati (serbuan spesies asing) ini akan menimbulkan berbagai dampak negatif seperti berbagai penyakit berbahaya bagi manusia, hewan maupun tumbuhan, serta dampak pada kerusakan keseimbangan lingkungan yang sangat sulit untuk dipulihkan (Surata, $d k k, 2009)$.

Indonesia tidak terlepas dari terjadinya invasi hayati. Sejak beberapa tahun terakhir di Indonesia telah terjadi serangan flu burung terhadap ternak unggas serta belakangan telah banyak juga terjadi serangan terhadap manusia. Serangan dan penyebaran penyakit ini berlangsung dengan cukup cepat di beberapa daerah di Indonesia. Untuk serangan terhadap ternak unggas hampir terjadi di semua propinsi di Indonesia. Belum berakhirnya permasalahan akibat penyakit flu burung, belakangan juga telah mulai muncul serangan flu babi. Penyakit ini juga awalnya menyerang pada ternak dan berimbas pada serangan terhadap manusia. Invasi lain yang cukup mengkhawatirkan adalah serangan berbagai hama dan penyakit pada komoditi pertanian dan perkebunan. Serangan Citrus Vein Phloem Degeneration (CVPD) pada tanaman jeruk telah menimbulkan kerugian yang besar bagi para petani jeruk. Para petani di beberapa daerah juga mengalami kerugian yang cukup besar akibat kerusakan yang dilakukan oleh hama tikus dan keong mas (FAO, 2007). Permasalahan hama ini sampai saat ini belum menemukan solusi yang tepat untuk mengatasinya. Pada sektor kesehatan masyarakat juga belum ditemukan solusi yang tepat untuk menekan angka kematian akibat penyakit Demam Berdarah Dengue (DBD) yang rutin setiap tahun mewabah ketika musim penghujan tiba. Selain itu akhir-akhir ini juga rabies mulai banyak menyerang khususnya di propinsi Bali terjadi kasus yang cukup banyak, padahal propinsi Bali sebelumnya merupakan daerah bebas rabies (Surata, $d k k, 2009$ ).

Pemerintah Indonesia sudah melakukan berbagai upaya dalam menanggulangi permasalahan munculnya berbagai penyakit tersebut. Pendekatan yang dilakukan pemerintah dalam mengatasi masalah tersebut adalah dengan pendekatan kasus per kasus yang dilakukan secara sektoral. Upaya pemerintah ini cenderung melakukan tindakan ketika suatu kasus telah terjadi. Sangat jarang adanya upaya mengatasi permasalahan ini dari aspek preventif sebagai upaya pencegahan. Diperlukan suatu upaya untuk mengatasi permasalahan ketahanan hayati secara terintegrasi dan holistik sehingga penanganan permasalahan ini tidak terkesan dilakukan secara sepotong-sepotong. Implementasinya adalah perlu dilakukan suatu upaya 
pemberdayaan masyarakat melalui pendidikan formal untuk memperkuat pemahaman tentang ketahanan hayati khususnya pada generasi muda. Untuk itu perlu dilakukan pengembangan literasi ekologi-sosial tentang isu-isu ketahanan hayati khususnya bagi mahasiswa calon guru, untuk meningkatkan kemampuan mereka dalam memahami interaksi antara masalah sosial dan ekologi, serta mampu menganilisis segala risiko dan dampak negatif invasi hayati untuk mengembangkan solusi dalam mengantisipasi dan mengelola risiko dan dampak buruk invasi hayati yang berkaitan dengan kehidupan masyarakat luas dan lingkungan hidup.

Dalam upaya memberikan pemahaman tentang literasi ekologi-sosial yang mencakup isu-isu ketahanan hayati kepada mahasiswa calon guru maka diterapkan model Ekoliterasi Ketahanan Hayati (EKH) pada mata kuliah Pengetahuan Lingkungan pada Program Studi Pendidikan Biologi Universitas Mahasaraswati Denpasar tahun akademik 2008/2009 (Surata, $d k k$, 2009). Permasalahan utama yang dihadapi dalam penerapan EKH adalah lemahnya aspek keterampilan berkelompok pada mahasiswa pendidikan biologi semester III FKIP Universitas Mahasaraswati Denpasar tahun akademik 2008/2009. Hal ini bisa diperbaiki dengan menggunakan metode pembelajaran kooperatif tipe kelompok investigasi pada kegiatan EKH. Metode kooperatif digunakan pada kegiatan EKH ini karena metode pembelajaran kooperatif memberi kesempatan kepada mahasiswa untuk mengembangkan keterampilan sosialnya sebagai individu-individu dalam kelompok. Pembelajaran kooperatif sangat menekankan kepada hakekat manusia sebagai makhluk sosial, yang selalu berinteraksi, saling membantu kearah yang semakin baik secara bersama-sama (Alma, $d k k$, 2009). Dalam proses berkelompok akan terjadi pertukaran pengetahuan dan saling memberikan informasi dan pengetahuan diantara anggota kelompok sehingga anggota kelompok dapat membangun pemahaman baru yang lebih baik terhadap suatu konsep.

Penerapan EKH ini menggunakan tipe kelompok investigasi karena tipe ini merupakan salah satu bentuk pembelajaran kooperatif yang akan melatih kemandirian mahasiswa dalam mencari sendiri materi (informasi) yang terkait dengan pelajaran yang dipelajari, sehingga mahasiswa dapat memiliki pemahaman yang lebih kuat terhadap suatu materi. Melalui penerapan model ini mahasiswa memiliki keterlibatan aktif dalam proses pembelajaran mulai dari tahap awal hingga tahap akhir pembelajaran. Dalam metode kelompok investigasi ini terdapat tiga konsep utama, yaitu: penelitian, pengetahuan, dan dinamika kelompok (Sudrajat, 2008). Penelitian di sini adalah proses dinamika mahasiswa memberikan respon terhadap masalah dan memecahkan masalah tersebut. Pengetahuan adalah pengalaman belajar yang 
diperoleh mahasiswa baik secara langsung maupun tidak langsung. Sedangkan dinamika kelompok menunjukkan suasana yang menggambarkan sekelompok saling berinteraksi yang melibatkan berbagai ide dan pendapat serta saling bertukar pengalaman melalui proses saling beragumentasi.

Penerapan EKH dengan metode kooperatif tipe kelompok investigasi dalam pelaksanaannya oleh mahasiswa dilakukan dengan menggunakan pendekatan artistik digital, yakni dengan presentasi kelompok menggunakan media berupa Microsoft Power point. Pendekatan artistik digital ini digunakan sebagai media untuk memperkuat proses sosial yang terjadi dalam pembelajaran karena akan membantu mengintegrasikan berbagai konsep ekologi, meningkatkan keseimbangan antara kecerdasan objektif (logika) dan subjektif (emosi). Dengan demikian mahasiswa akan dapat berlatih untuk menuangkan segala ide dan bangunan konsep yang telah diperolehnya melalui proses menemukan, penelitian dan tukar fikiran dalam kelompok untuk dirancang menjadi sebuah media pembelajaran berupa slide power point. Rancangan konsep dalam bentuk slide power point merupakan produk yang dihasilkan dari proses pembelajaran berkelompok dengan model investigasi kasus invasi hayati. Selanjutnya mahasiswa akan dilatih untuk mempresentasikan hasil pembelajarannya melalui presentasi kelompok dalam diskusi kelas. Dalam kesempatan ini mahasiswa akan melatih keterampilan mereka dalam penyampaian ide, menanggapi pertanyaan atau permasalahan dalam diskusi serta berlatih memperkuat aspek kerjasama antar individu sebagai suatu kesatuan kelompok.

Penerapan EKH pada mahasiswa Program Studi Pendidikan Biologi Universitas Mahasaraswati ini dilakukan sebagai upaya untuk meningkatkan keterampilan proses berkelompok mahasiswa serta untuk melatih mahasiswa dalam merancang media pembelajaran berbasis artistik digital. Kegiatan ini dilaksanakan dengan menggunakan Penelitian Tindakan Kelas (PTK) yang terdiri dari dua siklus. Penelitin ini dilakukan sebagai upaya untuk meningkatkan aspek-aspek keterampilan sosial yang harus dimiliki oleh seorang calon guru. Hal ini penting mengingat keterampilan sosial mutlak harus dimiliki oleh seorang guru selain juga kemampuan kognitif. Selama ini permasalahan yang dihadapi oleh mahasiswa calon guru ketika melakukan praktek mengajar adalah kurangnya keterampilan sosial yang dimiliki. Penerapan PTK dalam hal ini juga dimaksudkan untuk meningkatkan keterampilan mahasiswa calon guru dalam merancang media pembelajaran digital yang berupa power point. Hal ini sangat penting karena suatu proses pembelajaran sangat 
memerlukan media pembelajaran yang sesuai dan memadai. Faktanya bahwa banyak mahasiswa calon guru dan bahkan lulusan pendidikan keguruan yang kurang terampil dalam merancang media pembelajaran. Berdasarkan dua permasalahan tersebut maka penelitian EKH ini akan menekankan evaluasi pada dua aspek yakni pembelajaran kooperatif sebagai proses yakni pada peningkatan keterampilan berkelompok mahasiswa dalam proses presentasi kelompok serta produk yang dihasilkan dari proses pembelajaran kooperatif ini yaitu berupa power point yang dipresentasikan oleh masing-masing kelompok.

Adapun tujuan khusus dari pelaksanaan EKH berbasis pembelajaran kooperatif tipe kelompok investigasi dengan pendekatan artistik digital adalah: 1) Untuk mengetahui peningkatan keterampilan berkelompok yang dicapai mahasiswa calon guru biologi dalam presentasi oral berbasis power point pada penerapan pembelajaran kooperatif kelompok investigasi berbasis pendekatan artistik digital (power point) dalam pelaksanaan EKH. 2)Untuk mengetahui peningkatan keterampilan menyusun media pembelajaran power point yang dicapai mahasiswa calon guru biologi pada penerapan pembelajaran kooperatif kelompok investigasi berbasis pendekatan artistik digital (power point) dalam pelaksanaan EKH.

\section{METODE PENELITIAN}

Penelitian ini merupakan Penelitian Tindakan Kelas (PTK), dengan proses fleksibel, yang memungkinkan aksi (perubahan, dan perbaikan), dan penelitian (pengetahuan dan pemahaman) diperoleh secara bersamaan, sehingga dapat memberikan kontribusi praktis dalam mencari solusi permasalahan, dan meningkatkan aset pengetahuan komunitas sains sosial. Rancangan penelitian ini merupakan PTK dengan 2 siklus, masing-masing siklus dilakukan dengan 3 kali presentasi power point. Subjek penelitian adalah mahasiswa Program Studi Pendidikan Biologi Semester III Fakultas Keguruan dan Ilmu Pendidikan Universitas Mahasaraswati Denpasar tahun akademik 2008/2009. Sampel dalam penelitian ini terdiri atas 29 mahasiswa yang terbagi dalam 6 kelompok. Objek penelitian adalah kemampuan berkelompok dalam presentasi oral serta kemampuan dalam menyusun media pembelajaran power point pada kegiatan EKH dengan penerapan model pembelajaran kooperatif kelompok investigasi berbasis pendekatan artistik digital (power point). Penelitian ini dilakukan pada bulan Agustus - September 2009, yang mengambil tempat di Kampus Universitas Mahasaraswati Denpasar di Jalan Soka Denpasar. Penelitian ini dilakukan dalam dua siklus yang masing-masing terdiri dari 4 
tahapan yaitu : perencanaan, pelaksanaan, pengamatan/observasi, dan refleksi. Tahapantahapan penelitian yang akan dilakukan ditempat penelitian dimulai dari refleksi awal, dan dilanjutkan dengan siklus I. Setelah melakukan analisis dan refleksi terhadap kendala yang dihadapi pada siklus I, penelitian akan dilanjutkan pada siklus II.

Data yang dikumpulkan untuk analisis dalam penelitian ini meliputi data perilaku dan interaksi mahasiswa dalam berkelompok. Data tersebut meliputi beberapa aspek dalam proses presentasi oral oleh kelompok antara lain kemampuan kelompok dalam membuka presentasi, fokus kelompok dalam presentasi, organisasi penyajian dalam presentasi, suara dalam presentasi serta kerjasama dan kemampuan kelompok dalam tanya jawab. Penilaian juga dilakukan terhadap produk dari kegiatan ini yaitu media power point yang disusun oleh masing-masing kelompok. Adapun aspek-aspek yang dinilai dari media power point yang dihasilkan mencakup : gambaran umum, latar belakang, teks (pemilihan huruf dan format), serta keakuratan isi dalam alat bantu. Pengumpulan data tersebut dilakukan dengan penyebaran rubrik penilaian pada tim peneliti yang meliputi fasilitator reviewer (dalam hal ini adalah dosen), senior peer reviewer (kakak kelas) dan juga self reviewer (mahasiswa itu sendiri). Data prilaku berkelompok dalam presentasi power point akan mencerminkan mengenai bagaimana aktivitas kelompok tersebut dalam presentasi di depan kelas (Surata, dkk, 2009). Dalam tiap lembar penilaian rubrik dilakukan dengan memberikan nilai sesuai dengan kriteria, misalnya baik dengan nilai 4, sedang dengan nilai 3, cukup dengan nilai 2 dan kurang dengan nilai 1. Pada siklus I ada 3 kali presentasi oleh 3 kelompok demikian juga pada siklus II. Data dari siklus I dan II kemudian diolah dan dibandingkan. Analisis data ini dilakukan untuk mengetahui apakah ada peningkatan atau tidak terhadap keterampilan berkelompok mahasiswa dalam presentasi oral berbasis power point serta kualitas produk yakni slide power point antara siklus 1 dan siklus 2. Apabila ternyata terjadi peningkatan, maka akan diuji apakah peningkatan yang terjadi signifikan atau tidak. Analisis dilakukan uji komparasi dua sampel menggunakan uji median (median test).

\section{HASIL PENELITIAN}

Hasil pengamatan untuk perilaku berkelompok mahasiswa pada saat presentasi menunjukkan perbedaan nilai pada siklus 1 dan siklus 2, Pada pengamatan terhadap perilaku berkelompok nilai mahasiswa cenderung mengalami peningkatan hasil dari siklus 1 ke siklus 2. Data perilaku berkelompok mahasiswa pada saat presentasi oral diuji dengan 
menggunakan statistik non parametrik menggunakan uji beda median. Uji ini kemudian dilanjutkan dengan uji Fisher karena besarnya $\mathrm{n}<20$ (hanya 6 kelompok). Taraf kesalahan ( $\alpha$ ) ditetapkan $5 \%(0,05)$. Dari hasil analisis data diketahui bahwa untuk aspek pembukaan dalam presentasi memiliki nilai $\mathrm{P}=0,20$, hal ini berarti $\mathrm{P}>0,05$ menunjukkan bahwa perbedaan nilai pada aspek pembukaan adalah tidak berbeda nyata. Hal ini juga berarti bahwa peningkatan nilai pada aspek pembukaan dalam presentasi dari siklus 1 ke siklus 2 adalah tidak signifikan. Sementara untuk aspek fokus dalam presentasi, organisasi penyajian dan kemampuan tanya jawab menunjukkan nilai $\mathrm{P} \leq 0,05$, hal ini berarti bahwa peningkatan nilai rata-rata untuk aspek fokus dalam presentasi, organisasi penyajian dan kemampuan tanya jawab adalah signifikan. Adapun hasil analisis statistik untuk kemampuan berkelompok mahasiswa dalam presentasi oral berbasis power point disajikan pada Tabel. 1 .

Tabel 1. Data Kemampuan Kelompok dan Analisis Statistik Kemampuan Mahasiswa dalam Presentasi Oral

\begin{tabular}{|c|c|c|c|c|c|c|}
\hline \multirow[t]{2}{*}{ No } & \multirow[t]{2}{*}{ Aspek yang Dinilai } & \multicolumn{2}{|c|}{ Nilai Mahasiswa } & \multicolumn{2}{|c|}{ Nilai P } & \multirow[t]{2}{*}{ Keterangan } \\
\hline & & Siklus 1 & Siklus 2 & Hitung & $5 \%$ & \\
\hline 1 & Pembukaan & 2,82 & 3,35 & 0,20 & 0,05 & Ho diterima \\
\hline 2 & Fokus dalam Presentasi & 2,86 & 3,73 & 0,05 & 0,05 & Ho ditolak \\
\hline 3 & Organisasi Penyajian & 2,90 & 3,62 & 0,05 & 0,05 & Ho ditolak \\
\hline 4 & Suara dalam Presentasi & 3,42 & 3,81 & 0,05 & 0,05 & Ho ditolak \\
\hline 5 & Tanya Jawab & 3,18 & 3,85 & 0,05 & 0,05 & Ho ditolak \\
\hline
\end{tabular}

Berdasarkan evaluasi yang dilakukan terhadap produk hasil kegiatan pembelajaran yang berupa slide power point maka didapatkan hasil bahwa slide power point yang dihasilkan oleh mahasiswa cenderung mengalami peningkatan dari siklus 1 ke siklus 2 , Kecenderungan peningkatan ini terjadi pada semua aspek penilaian terhadap media power point yang dihasilkan oleh mahasiswa, Kecenderungan nilai media power point mahasiswa ini juga diuji signifikansinya dengan uji beda median yang dilanjutkan dengan uji Fisher. Data nilai dari media power point yang dihasilkan oleh mahasiswa serta uji signifikansinya disajikan pada Tabel. 2 . 
Tabel 2. Data Nilai dan Analisis Statistik Media Power Point yang dibuat oleh Mahasiswa

\begin{tabular}{lllllll}
\hline \multirow{2}{*}{ No } & Aspek yang Dinilai & \multicolumn{2}{c}{ Nilai Mahasiswa } & \multicolumn{2}{c}{ Nilai P } & Keterangan \\
\cline { 3 - 6 } & & Siklus 1 & Siklus 2 & Hitung & $5 \%$ & \\
\hline 1 & Gambaran Umum & 3,38 & 3,76 & 0,45 & 0,05 & Ho diterima \\
2 & Latar Belakang & 3,17 & 3,56 & 0,05 & 0,05 & Ho ditolak \\
3 & Teks (Huruf dan Format) & 3,17 & 3,23 & 0,45 & 0,05 & Ho diterima \\
4 & Keakuratan Isi dalam Alat Bantu & 3,12 & 3,62 & 0,05 & 0,05 & Ho ditolak \\
\hline
\end{tabular}

Berdasarkan hasil uji statistik non parametrik diatas dapat diketahui bahwa untuk aspek latar belakang dan keakuratan isi dalam alat bantu memiliki nilai $\mathrm{P} \leq 0,05$ hal ini berarti bahwa perbedaan nilai dari siklus 1 dan 2 pada kedua aspek tersebut adalah berbeda nyata sehingga dapat dikatakan bahwa pada kedua aspek tersebut terjadi peningkatan nilai yang signifikan dari siklus 1 ke siklus 2 . Hal yang sebaliknya terjadi pada aspek gambaran umum dan teks, Pada kedua aspek ini tidak terjadi perubahan nilai yang signifikan dari siklus 1 ke siklus 2 karena berdasarkan uji statistik non parametrik nilai $\mathrm{P}>0,05$.

\section{PEMBAHASAN}

Berdasarkan hasil penelitian dan hasil analisis data yang telah dilakukan maka dapat diketahui bahwa penerapan pembelajaran kooperatif kelompok investigasi dengan pendekatan artistik digital (power point) telah mampu meningkatkan keterampilan berkelompok mahasiswa dalam presentasi oral pada pembelajaran EKH bagi mahasiswa semester III Program Studi Pendidikan Biologi Universitas Mahasaraswati Denpasar. Hal ini karena pembelajaran kooperatif dengan model kelompok investigasi dapat melatih siswa untuk menumbuhkan kemampuan belajar secara mandiri sehingga dapat mengasah kemampuan berpikir dan kreatifitas dari mahasiswa. Mahasiswa akan memiliki kemampuan untuk memberikan respon terhadap masalah dan memecahkan masalah tersebut. Hal ini sesuai dengan pendapat Sudrajat (2008) yang menyatakan bahwa pemecahan masalah dalam pembelajaran kooperatif dilakukan melalui interaksi (dinamika proses) di dalam kelompok belajarnya sehingga terjadi saling tukar pengetahuan antara mahasiswa yang satu dengan 
mahasiswa yang lainnya melalui proses berargumentasi di dalam kelompok belajar maupun antar kelompok belajar.

Dinamika proses yang terjadi di dalam kelompok belajar akan dapat memperkuat perilaku berkelompok mahasiswa. Dengan adanya kerjasama, rasa saling ketergantungan positif serta keinginan untuk menyamakan persepsi dan pemahaman terhadap pengetahuan, maka masing-masing anggota akan berusaha optimal untuk mengkontribusikan pengetahuan serta menjalankan tugasnya dengan sebaik-baiknya pada saat pembelajaran kooperatif. Dengan demikian maka akan tercapai tujuan kelompok yaitu kelompok yang utuh, yang mampu membangun dan menyamakan persepsi pengetahuan anggotanya dalam pembelajaran yang berlangsung. Hal ini didukung oleh hasil penelitian Ekayanti (dalam Surata, $d k k, 2009$ ) yang menyebutkan bahwa penerapan metode pembelajaran kooperatif tipe kelompok investigasi, telah mampu meningkatkan aspek partisipasi anggota dalam kelompok, pembagian tanggung jawab dalam kelompok, kualitas interaksi, serta peranan anggota dalam kelompok.

Melalui model pembelajaran kooperatif yang diterapkan pada penelitian ini, akan memberikan kesempatan yang lebih luas kepada mahasiswa untuk berinteraksi dalam kelompoknya sehingga dapat menghasilkan ide dan solusi baru untuk memecahkan suatu permasalahan. Kelompok memungkinkan orang saling tukar informasi dan pendapat. Kebiasaan berinteraksi dalam kelompok inilah yang akan dapat meningkatkan keterampilan sosial dan keterampilan berkelompok mahasiswa melalui pengembangan aspek-aspek yang ada di dalamnya yang dalam penelitian ini tercermin dari peningkatan kemampuan presentasi kelompok mahasiswa. Hal ini sesuai dengan pendapat Omith (2008) bahwa kelompok memiliki pengetahuan yang luas dan probabilitas yang lebih besar, sehingga seseorang dalam kelompok akan memiliki pengetahuan khusus yang relevan dengan persoalan kelompok.

Kebiasaan berinteraksi dalam kelompok dapat memperkuat terjadinya kohesi sosial dalam proses pembelajaran yang dilakukan oleh mahasiswa. Adanya kohesi sosial yang kuat akan memberikan dampak positif berupa peningkatan kemampuan berkelompok serta berinteraksi dalam kelompok untuk mencapai tujuan bersama. Peningkatan kohesi sosial ini salah satunya dapat ditingkatkan dengan penerapan metode pembelajaran kooperatif tipe kelompok investigasi. Hal ini berkorelasi dengan hasil penelitian dari Praptiningsih (dalam Surata, $d k k, 2009)$ yang menyebutkan bahwa penerapan model pembelajaran kooperatif tipe kelompok investigasi akan dapat menumbuhkan dan memperkuat aspek-aspek kohesi sosial 
yang terjadi di dalam sebuah kelompok belajar. Berdasarkan hasil penelitian Praptiningsih diketahui bahwa peningkatan kohesi sosial tercermin dari adanya peningkatan pada aspek kepercayaan pada kelas, pearasaan aman jika meninggalkan barang di kelas, keyakinan terhadap kelompok atau kelas dalam hal saling membantu, kepercayaan terhadap perangkat kelas, serignya mengikuti kegiatan baik di dalam kampus maupun di luar kampus berupa pengabdian pada masyarakat dan adanya kebebasan dalam mengeluarkan pendapat. Sehingga jelaslah bahwa penerapan pembelajaran kooperatif tipe kelompok investigasi akan dapat memperkuat kerjasama dan rasa saling percaya antar anggota kelompok yang dapat menumbuhkan ketrampilan setiap anggotanya dalam proses pembelajaran melalui adanya penguatan kohesi sosial diantara anggotanya.

Perpaduan antara pembelajaran kooperatif model kelompok investigasi dengan pendekatan artistik akan dapat mendorong proses pembelajaran menjadi kontruktif, transformatif dan kolaboratif, karena melalui seni memungkinkan mahasiswa menggambarkan pikiran, konsep dan perasaannya dalam bentuk beragam, yang bisa dibaca oleh orang lain. Pada pihak lain, mengajar juga bisa dikatakan sebagai suatu seni, karena mengajar bisa memiliki bentuk dan isi, seperti sebuah seni (Kinarawati, 2008). Para guru (termasuk mahasiswa calon guru) adalah seniman, karena mereka dapat menciptakan, berimajinasi dan berkomunikasi seperti seniman dalam menyampaikan materi pembelajaran, Sehingga dengan menggunakan dukungan media pembelajaran berbasis artistik digital akan dapat lebih memberikan daya tarik bagi pembelajar serta memudahkan dalam mendiskripsikan materi pembelajaran. Hal ini sesuai dengan hasil penelitian Putra, $d k k$ (2006), tentang Penggunaan Media Bergambar Berbasis Pendekatan Komunikasi Total yang diterapkan pada anak tuna rungu serta anak SD, yang menyatakan bahwa penggunaan media gambar yang dikombinasikan dengan adanya komunikasi secara total yaitu berupa pertemuan rutin, adanya saling interaksi serta adanya pemahaman berupa motivasi-motivasi yang diberikan lewat pengajar atau fasilitator dapat meningkatkan daya ingat, pemahaman informasi, terpacunya anak untuk berbicara serta mengungkapkan pendapat.

Berdasarkan hasil penelitian yang telah dilakukan diketahui bahwa pada aspek pembukaan presentasi, belum mengalami peningkatan yang signifikan dari siklus 1 ke siklus 2. Hal ini disebabkan karena mahasiswa yang baru semester III belum terbiasa tampil sebagai pembicara dalam sebuah seminar serta belum terbiasa dalam merancang media pembelajaran berupa slide power point. Mereka umumnya masih canggung dalam melakukan presentasi 
meskipun sudah diberikan masukan-masukan pada saat proses refleksi berlangsung. Umumnya mahasiswa terbiasa dengan perkuliahan dengan sistem yang hanya memposisikan mereka pada posisi sebagai obyek pembelajaran. Akibatnya pada proses ini ketika mahasiswa mendapat tugas untuk berbicara di depan kelas mereka masih memiliki kelemahankelemahan antara lain sebagaimana hasil penelitian ini, mahasiswa belum mampu melakukan pembukaan dengan baik. Menurut Lie (2002) aspek pembukaan merupakan suatu aspek yang harus dikuasai betul oleh seorang calon guru.

Dua aspek lainnya yang belum mengalami peningkatan yang signifikan pada penelitian ini adalah pada aspek dari merancang media pembelajaran power point, yakni dari aspek gambaran umum dan penggunaan teks. Hal ini berkaitan erat dengan keterampilan presentasi mahasiswa khususnya pada aspek pembukaan, karena kurangnya kemampuan mahasiswa dalam membuat gambaran umum yang akan disajikan dalam slide power point menunjukkan bahwa mahasiswa belum mampu menguasai urutan / alur presentasi secara baik yang juga. Mahasiswa kurang terbiasa mengasah kemampuan berfikir secara sistematis dalam penyampaian ide-ide serta topik-topik yang akan dibahas sehingga terlihat mahasiswa sedikit melebar dalam menyampaikan gambaran umum terhadap suatu permasalahan.

Pada aspek teks yang mencakup pada format slide dan pemilihan huruf juga belum terjadi peningkatan dari siklus 1 ke siklus 2 . Hal ini karena penyusunan format slide dan juga pemilihan huruf yang tepat sangat dipengaruhi oleh kemampuan dan keahlian mahasiswa untuk menampilkan aspek seni dan menarik pada slide sehingga kemampuan ini cukup sulit untuk dinilai dan cenderung berlaku relatif untuk masing-masing individu. Namun demikian setelah melakukan proses pembelajaran mahasiswa setidaknya sudah mendapatkan tambahan pengetahuan dari terjadinya dinamika proses dalam kelompok serta proses dalam presentasi kelas. Hal ini tentu akan memberikan nilai positif bagi mahasiswa.

Berdasarkan hasil penelitian yang telah dilakukan, menunjukkan bahwa diperlukan waktu yang lebih lama untuk dapat meningkatkan kemampuan mahasiswa pada aspek-aspek keterampilan berkelompok dalam presentasi oral sehingga untuk mencapai hasil yang maksimal belum cukup hanya dilakukan selama 2 siklus penelitian saja. Pada proses berkelompok ini keberhasilan peningkatan nilai pada aspek-aspek presentasi power point maupun pembuatan slide power point (produk) akan sangat ditentukan oleh dinamika proses yang terjadi di dalam kelompok. Berdasarkan hasil pengamatan diketahui bahwa walaupun sudah dilakukan proses evaluasi dan refleksi dengan memberikan koreksi dan perbaikan 
setelah siklus satu, ternyata mahasiswa masih banyak yang belum mampu melakukan proses yang dapat mengangkat nilai kelompok secara keseluruhan, proses berkelompok yang terjadi baru mampu memberikan peningkatan hanya kepada keterampilan sosial mahasiswa secara individu.

Adapun beberapa kelemahan yang masih ada pada siklus satu antara lain kelemahan dari sisi perilaku anggota dalam proses pembelajaran kooperatif. Masih ada beberapa mahasiswa di kelompok-kelompok tertentu yang kurang mampu beradaptasi dengan kelompoknya sehingga tidak mampu menjalankan peranan/tugasnya di dalam kelompoknya. Masih banyak anggota kelompok yang tidak mau berpartisipasi secara aktif dalam kegiatan kelompok. Anggota kelompok ketika melakukan diskusi kurang dapat menggunakan bahasa dengan baik/penggunaan bahasa agak kacau. Ketika melakukan diskusi/tanya jawab ada anggota kelompok cenderung memberikan jawaban yang tidak menunjukkan penguasaan materi sehingga sering terjadi perdebatan yang cenderung membias.

Kelemahan yang terjadi pada waktu presentasi antara lain, mahasiswa masih belum mampu membuka jalannya presentasi dengan baik. Pada saat melakukan presentasi maksud dan tujuannya kurang jelas sehingga sering terjadi bahwa presentasi yang dilakukan menjadi tidak fokus. Pada saat penyajian materi umumnya tidak disampaikan dengan organisasi yang baik sehingga dalam penyampaiannya banyak terdapat ide-ide yang tidak saling berhubungan. Kelemahan ditinjau dari media power point yang dibuat antara lain, pesan yang ingin disampaikan cenderung terpisah dari ilustrasi, sehingga ada pesan yang tidak tersampaikan kepada pendengar. Hal ini terlihat dari pembuatan ilustrasi dan gambar yang ditampilkan dalam media power point yang dibuat tidak sesuai dan tidak mendukung substansi / isi materi yang disajikan. Ilustrasi dan isi terlihat menjadi dua bagian yang masing-masing berdiri sendiri dan terpisah. Kelemahan lainnya yang masih terlihat adalah pada penyusunan latar belakang slide yang terlalu banyak dan tidak efektif sehingga menyebabkan sulit melihat teks atau ilustrasi.

\section{SIMPULAN DAN SARAN}

Penerapan pembelajaran kooperatif kelompok investigasi berbasis pendekatan artistik digital (power point) dalam EKH pada mahasiswa calon guru biologi dapat meningkatkan keterampilan berkelompok mahasiswa dalam presentasi oral berbasis power point pada aspek fokus dalam presentasi meningkat dari 2,86 menjadi 3,73 ( $\mathrm{p}=0,05)$, pada aspek organisasi 
penyajian dari 2,90 menjadi $3,62(\mathrm{p}=0,05)$, suara dalam presentasi meningkat dari 3,42 menjadi 3,81 ( $\mathrm{p}=0,05)$ serta kemampuan tanya jawab dari 3,18 menjadi 3,85 (p=0,05) sedangkan pada aspek pembukaan presentasi terjadi peningkatan dari 2,82 menjadi 3,35 (p = $0,20)$ namun peningkatannya tidak signifikan.

Penerapan pembelajaran kooperatif kelompok investigasi berbasis pendekatan artistk digital (power point) dalam EKH bagi mahasiswa calon guru biologi dapat meningkatkan keterampilan mahasiswa dalam menyusun media pembelajaran berupa power point ditinjau penyusunan latar belakang meningkat dari 3,17 menjadi 3,56 $(p=0,05)$ serta dari keakuratan isi dengan alat bantu meningkat dari 3,12 menjadi 3,62 (p = 0,05) sedangkan untuk aspek penyusunan gambaran umum meningkat dari 3,38 menjadi $3,76(\mathrm{p}=0,45)$ serta teks yang mencakup pemilihan huruf dan format meningkat dari 3,12 menjadi 3,62 ( $\mathrm{p}=0,45)$ namun peningkatan yang terjadi tidak signifikan.

Berdasarkan hasil yang dicapai pada penelitian ini, maka saran yang dapat disampaikan adalah : 1) Diharapkan kepada dosen untuk dapat menerapkan pembelajaran kooperatif tipe kelompok investigasi pada mata kuliah lain, karena model pembelajaran kooperatif tipe kelompok investigasi dapat meningkatkan keterampilan berkelompok mahasiswa serta meningkatkan aspek sosial mahasiswa terutama kemampuan berinteraksi mahasiswa. 2) Disarankan kepada pembaca terutama guru dan calon guru untuk menerapkan perpaduan antara pembelajaran kooperatif model kelompok investigasi dengan pendekatan artistik dalam mengajar karena akan dapat mendorong proses pembelajaran menjadi konstruktif, transformatif dan kolaboratif, karena melalui seni memungkinkan mahasiswa menggambarkan pikiran, konsep dan perasaannya dalam bentuk beragam, yang bisa dibaca oleh orang lain. 3) Disarankan kepada para pembaca dan peneliti untuk dapat melakukan penelitian lanjutan terkait penerapan metode pembelajaran kooperatif tipe kelompok investigasi dengan pendekatan artistik untuk meningkatkan keterampilan mahasiswa dalam presentasi oral berbasis power point khususnya pada aspek pembukaan presentasi. Untuk meningkatkan keterampilan mahasiswa dalam menyusun media pembelajaran berupa slide power point khususnya untuk aspek penyusunan gambaran umum dan teks yang mencakup pemilihan huruf dan format.

\section{DAFTAR PUSTAKA}

Alma B, Mulyadi H, Razali G, Nuryati L. 2009. Guru Profesional Menguasai Metode dan Terampil Mengajar. Bandung : Alfa beta 
Arikunto, S. 2002. Dasar-dasar Evaluasi Pendidikan. Jakarta: Bumi Aksara.

Capra, F. Literacy Ecologi. http://www.danceyourlife.eu/sourcesofbiodanza/ FritjofCapra.html. Diakses 16 april 2010

Food and Agriculture Organization of the United Nations [FAO]. 2007. FAO biosecurity toolkit, Rome.

Falk I, Surata, SPK, Mudita W, Martiningsih E \& Myers B. 2008, pp 1-40. In I Falk, K surata, K Suwondo (eds). Community Management of Biosecurity. Overview of Some Indonesian Studies. Community Management of Biosecurity. English Language Edition. Special Co-Publication 2008 between Learning Communities (International Journal of Learning in Social Contexts) Australia, and Kritis (Journal of Interdisiplinary Development Studies) Indonesia.

Hakim, Thursan. 2005. Belajar Secara Efektif. Jakarta: Puspa Swara.

Jubandu, A. 2008. Interaksi Individu dalam Kelompok Sosialnya.

http://gurupkn.wordpress.com/2008/06/23/kegiatan-pembelajaran-kooperatif dan penerapannya di Sekolah/. Diakses tanggal 28 Maret 2010.

Kinarawati. 2008. Kegiatan Pembelajaran dan Pemilihan Media Pembelajaran. http://gurupkn.wordpress.com/2008/01/17/kegiatan-pembelajaran-dan-pemilihanmedia-pembelajaran/. Diakses tanggal 23 April 2010.

Kemmis, WC. \& Taggart. 1998. The Action Research Planner. Geelong Victoria : Deakin University Press.

Kresna.2009.Penelitian eksperimen serta penelitian seperti eksperimen. http://skripsikonsultasi.blogspot.com/2009/07/penelitian-eksperimen-serta-penelitian.html. Diakses 7 Des 2009.

Lie, Anita. 2002. Cooperative Learning. Jakarta: PT Gramedia. Cet. Ke-5

Omith.2008.Prinsip-Prinsip dan Dasar Dasar Komunikasi Dalam Kelompok http://kuliah.dagdigdug.com/2008/07/12/prinsip-dasar-komunikasi-dalam-kelompok/

Puk T. 2002. Ecological Literacy as the first imperative. http://flash. lakeheadu.ca/ tpuk/Version\%20Principles.pdf, diakses 16 April 2010.

Putra, T, Erwin, NV, Rudi, S. 2006. Penggunaan Media Bergambar Berbasis Pendekatan Komunikasi Total pada Anak Tuna Rungu dan Anak SD.. Jakarta : Dikti.

Slavin. 1995. Cooperative Learning Theory. Second Edition. Massachusetts: Allyn and Bacon Publisher.

Sugiyono. 2009. Statistik Non Parametrik untuk Penelitian. Bandung : Alfa beta

Surata SPK, Martiningsih E, Vipriyanti NU. 2009. Pendekatan artistik dalam pendidikan ketahanan hayati: pengembangan model literasi ekologi-sosial bagi mahasiswa calon guru. Hibah penelitian unmas. Tidak diterbitkan

Suryanto, 2009. Perilaku Kelompok Dan Individu.http: suryanto.blog.unair.ac.id 2009.02.11.prilaku-kelompok-dan-individu. Diakses 3 November 2009

Sudrajat, Akhmad. 2008. Penilaian Hasil Belajar. http: akhmadsudrajat.wordpress. com 2008. 05. 01 penilaian-hasil-belajar. Diakses 12 November 2009

Suwasono, Soemitro, BS, Spekartomo, S. 1989. Pengantar Ekologi. Jakarta. CV Rajawali.

Syaodih, Erliany. 2008. Cooperative Learning. http://educare.e-fkipunla.net/ index 2.php?option $=$ com content $\&$ do $\_$pdf $=1 \& i d=10$. Diakses 7 Nov 09

Wikipedia. 2008. Ekologi. http://id.wikipedia.org/wiki/Ekologi. Diakses tanggal 7 Novovember 2009. 
Jurnal Santiaji Pendidikan, 2011, 1(1): 62-75

ISSN 2087-9016 